\title{
BIRDS THAT I \\ THOUGHT I HAVE KNOWN
}

KEITH BARR, 40 Richardson Crescent, Regina, Saskatchewan. S4S 4J3

I am an avid bird watcher and photographer. I have always been interested in nature. Even as a child I knew the common birds of the area House Sparrows, crows, magpies, robins, Red-winged Blackbirds, etc. In my adult years I became interested in photography due to my work. My then teenage son had the same interests and we would often go together to photograph birds. We were fortunate to get pictures of Whooping Cranes and of Sharp-tailed Grouse on their dancing grounds. I think that these pictures of the grouse were the start of my problem.

At work, a fellow employee was giving photography lessons to interested people. He knew that my son and I had a small collection of bird and animal slides. He asked me if I would give a lecture on wildlife photography. I accepted naively. I was showing slides to the photo class, when I got to the slides of the Sharptailed Grouse. It was a nice picture of a grouse that had come quite close and the picture just about filled the screen. I stated that this was a female sharp-tail that had wandered over to see what my son and I were up to. Out of the dark, from the back of the room booms a very authoritative voice, "That is not a female; that is a male. See that yellow patch above the eye. Only males have that yellow patch."

The second such incident happened in just about the same way. I was showing slides to a natural his- tory group. I should have known better! A slide of a small colourful shorebird came on the screen. I opened my mouth and these words came forth, "This is a male Wilson's Phalarope." You guessed it. Out of the dark recesses I hear this authoritative voice say, "That is not a male. That is a female." Why can't these people come to you after the showing and quietly point out your slight misjudgement?

It is the spring of the year and my wife and $I$ are sitting on the back patio drinking coffee. We still have our bird feeder going and are feeding the horde of local sparrows. I notice a sparrow-like bird that is different. The breast is heavily streaked and the bill is thicker. It looks like some kind of a sparrow to me. I don't want iny coffee to get cold while I look it up in the bird books, so I get my camera and take a couple of pictures of it. As I cannot concentrate on two things at the same time, I drink my coffee and forget about the bird.

In the late afternoon the bird is back at the feeder. I am not doing anything at the time so now I can concentrate on the bird. I get the bird books out and I think that I have found what the bird is. It is not supposed to be here in Saskatchewan. To be sure, I go through the books three more times to see if it may be another bird that I missed. I am hesitant to identify it as a female House Finch, but it is. (See Blue Jay, September 1990, page 167.) I phone the 
Rare Bird Alert with the identification of the bird. The Rare Bird Alert is a phone number that you can call which gives any unusual sightings of birds in the area. If you have any sightings to report, you wait until the end of the tape and then leave your message. The message is updated almost every day.

I get a couple of phone calls from people wanting to see the House Finch. Alas, it has gone. These avid bird watchers ask me to phone them should the finch return. I should end here while I have one out of three, but I never know when to quit.

Ten days later, my wife and I are sitting on the back patio drinking coffee (our favourite pastime in the spring) when I see this sparrow-type bird come to the feeder. It has a streaked breast. I immediately go to the house and phone the avid birders that the House Finch is back. I want more pictures of this rare bird so I grab my camera and go back outside. I inch towards the bird. It seems different, but I want it to be a House Finch, so a House Finch it is. I take several pictures. The bird watchers arrive; the bird is gone. I feel that the bird will be back. I have an appointment and have to leave but the bird watchers are welcome to stay and they do. On returning an hour later, only one bird watcher is left. I ask him if the bird had returned. He replied that it had. I think I hear just a hint of scorn in his voice when he tells me that it was not a House Finch but only a Pine Siskin. How was I to know? I had never seen a Pine Siskin before!

Later the same year, I am out birding by myself and I see a white bird in the water, wading about. It is the size of what I think a Snowy Egret should be. In the past I have heard of Snowy Egrets in Saskatchewan, but have never seen one. This is my first Snowy Egret. I return home and call the Rare Bird Alert as well as several birders and tell them of my find. I cannot view the bird again due to other commitments. That evening when I return home my answering machine is flashing. It has a couple of messages for me. I listen to the two messages. Was there a hint of ridicule in those authoritative voices as I was informed that the bird I had reported was not a Snowy Egret but a Little Blue Heron?

I am getting to the point that if I see a bird that is not a House Sparrow, crow or robin, I say, "There goes an L.B.B." (a little brown bird). Can you really blame me?

The Audubon Christmas Bird Count for December/92-January/93 had over 43,000 participants. Six hundred and thirty-seven species, totalling $54,000,000$ birds, were found on over 1,600 counts in North America. In Central and South America, 1,405 species were found on 47 counts. American Birds 47:478. 